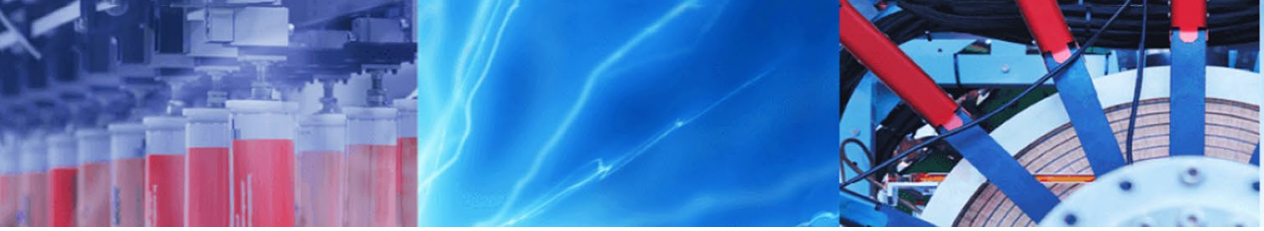

Research Article

\title{
Impact of rice husk ash (RHA) and nylon fiber on the bearing capacity of organic soil
}

\author{
Tonmoy Kumar Brahmachary ${ }^{1}$ Md. Kamrul Ahsan ${ }^{1} \cdot$ Md. Rokonuzzaman ${ }^{1}$
}

(c) Springer Nature Switzerland AG 2019

\begin{abstract}
In the south-west part of Bangladesh, the regular systems of foundation are not suitable for the massive structure because an organic soil layer exists at a distance of 3-6 m from the ground surface. The existence of organic soil layer causes excessive settlement due to its high compressibility and low shear strength. To solve this matter, soil improvement is needed indispensably because it drops the construction expense and decreases the risk of further damage to the structures. Soil stabilization is an important method in the field of construction. The techniques of stabilization are used to enhance the strength of expansive or poor organic soil. In Bangladesh, huge amounts of industrial wastes are being produced every year due to fast urbanization and industrialization. Disposal of these waste materials is important as these are creating harmful effects on the environment. Rice husk ash (RHA) and nylon fibers are enormously available as industrial waste are dangerous if not disposed technically. Utilization of these industrial waste in ground improvement is likely to offer an admissible solution. This research represents the investigational results acquired from tests performed on organic soil stabilized with RHA and strengthened with randomly distributed nylon fibers. To investigate the impact of RHA and nylon fiber on strength properties of organic soil, standard proctor compaction, unconfined compressive strength (UCS), unsoaked and soaked CBR tests were conducted first on the soil samples partially replaced by RHA with dose $0 \%, 5 \%$, $10 \%, 15 \%, 20 \%$ and then soil plus optimum percent of RHA and different content of nylon fiber $(0.3 \%, 0.5 \%, 0.7 \%, 1 \%$, 1.2\%). The experimented results disclose that inclusion of different dosages of RHA and nylon fiber in organic soil leads to increase in the optimum moisture content and decrease in maximum dry density. The experimental results also express that the suggested technique is very effectual to improve the strength properties of poor organic soil in words of UCS, unsoaked and soaked CBR values. The result of this research work can be used as a guideline for soil improvement and can be used in the field of civil engineering.
\end{abstract}

Keywords Organic soil · Soil stabilization - Bearing capacity · Maximum dry density - Optimum moisture content . Unconfined compressive strength · Unsoaked CBR · Soaked CBR · Rice husk ash · Nylon fiber

\section{Introduction}

Soil is the upper most share of earth and it is cheapest and freely available construction material. Soil is a mixture of natural raw materials (minerals), organic and inorganic substance, gases, fluids, and uncounted organisms that simultaneously support life on earth. It is typically categorized into four simple types such as Gravel, Sand, Clay and Silt [1]. Soil is made by the disruption of rocks and through the succeeding divergence, transportation and weathering of the products of decomposition. Soil also may consist of accumulations of organic peats, inorganic deposits, plants roots and numerous trashes and rubbles of an industrialized society [2]. Inorganic soils derieved from weathring of rocks. Organic soils are formed in place by decay of planet and animal. The soils will be defined

Tonmoy Kumar Brahmachary, tonmoybrahmachary@yahoo.com | ${ }^{1}$ Department of Civil Engineering, Khulna University of Engineering and Technology (KUET), Khulna 9203, Bangladesh.

SN Applied Sciences (2019) 1:273 | https://doi.org/10.1007/s42452-019-0275-0 
'organic soil' once their organic content exceeds $20 \%$ of their dry weight [3]. Organic soil is contained peat or fine, coarse or very coarse soil with an organic content [4]. Soil has poor tensile and shear strength and its characteristics may highly influence on the environmental conditions (e.g. dry vs wet) [5]. Soil is considered one of the most important and principal materials for any types of construction work globally. The strength and durability of any infrastructure directly depends on the underlying soil strength properties. Therefore, it is very essential to confirm that the soil over which any infrastructure is constructed, is secure or sufficient stable.

Khulna is 3rd major metropolitan and 2nd port city of Bangladesh, which is positioned on south-west section of the country. The earth in this part is formed by the sedimentary deposits from different rivers (Vairab, Rupsha and so on). This region is also enclosed by the world largest mangrove forest, Sundarban. These deep forests were buried underneath at different times in the past because of tectonic forces [6]. For these reasons, the soil is very soft, compressible having organic material with low bearing capacity [7]. High moisture content, high compressibility and poor workability of this weak soil habitually created problems in civil engineering construction programs [3, 8]. Construction cost in this area is very high for decent infrastructure [9]. Therefore, constructions in such type of places requisite superior consideration to overcome probable shear failure as well as total and differential settlements $[9,10]$ and minimize the cost of construction.

Improvement of strength properties is an indispensable need, when any infrastructures are created on a weak or poor-quality soil such as expansive, liquefiable, collapsible, dispersive, soluble, silty fine sands and highly organic $[11,12]$. This weak soil may create cracks and damage on the structures and may lead to failure of the structure at a later stage [13]. Therefore, it is important to take away the existing weak soil and exchanged it with a non-expansive soil or increases the strength properties of such poor/ weak soil by stabilization. Soil stabilization is one of the most important topics in geotechnical engineering practices. It is a technique introduced almost 500 years before. Soil stabilization has long historical background with hundreds of research results. Different types of method or technique have been developed over the years for soil stabilization in particular and ground improvement in general. These methods can be broadly divided into three categories, such as mechanical methods, chemical methods, and physical methods. Soil stabilization can be defined as a common word for any physical, chemical, biological or combined process of modifying the properties of an ordinary soil to meet an engineering purpose [14]. Soil stabilization can be undertaken by a diversity of ground improvement practices such as compaction, strengthening, drainage and inclusion of natural and synthetic substances or an arrangement of chemical and physical techniques $[15,16]$. The key purpose of soil stabilization is render the soil and make it stable enough to meet basic requirements of the specific engineering project.

Chemical stabilization is an alternative low-cost solution. Lime-cement $[17,18]$ and other pozzolanic ingredients are most common construction resources which are broadly used for stabilization of weak soils. In recent year, environmental issues have driven attention to apply industrial byproduct as construction ingredient [19]. Weak organic soil or other poor expansive soil has been stabilized using different types of industrial eco-friendly and/or waste materials like rice husk ash $[8,20]$, fly ashwood ash [21], bottom ash [22], pond ash-marble dustlime [23], bagasse ash-eggshell powder [24], coal ash [25], cement kiln dust [26], lime sludge [27], lime-stone dust [28], ceramic dust [29], quarry dust [30] and so on. These waste materials are attracted the attention of researchers because of their low cost and high pozzolanic action. Rice husk is an Argo-industrial waste. About 0.480 billion tons of milled rice ( 0.715 billion tons of paddy rice) are produced worldwide [31] and generate 0.10 billion tons of husk [32]. Around 0.0393 billion tons of rice is produced per year in Bangladesh [33] which generate approximately 0.00983 billion tons of rice husk [8]. The RHA is better than other waste materials and has great ability to work in soil improvement due to existence of greater percentage of reactive silica in it. The RHA comprises almost $90 \%$ of silica [34], which is the highest concentration of all plant remainders [35]. Based on temperature range and burning time of the rice husk, crystalline and non-crystalline/amorphous forms of silica are found [36]. The type of ash appropriate for pozzolanic activity is amorphous rather than crystallized. The most important key factors are proper burning and grinding to get maximum content of reactive RHA. The ash manufactured by controlled burning of rice husk in the temperature between 500 and $800{ }^{\circ} \mathrm{C}$ is normally found to produce amorphous silica while temperatures in excess of $800^{\circ} \mathrm{C}$ produce undesired crystallized forms. The maximum content of amorphous silica is found in rice husk anneal in the temperature range of $500-700{ }^{\circ} \mathrm{C}$ [37]. To consider this, RHA has been used globally to improve strength properties of poor/weak soil with or without addition of a fluid activator like lime and cement [32, 38-40]. These cementitious ingredients transform and stabilize poor or weak soil through cation interchange, flocculation and agglomeration and reactions [8, 41, 42].

In 1966, Vidal of France introduce the concept of reinforced soil technique. It is a physical method of ground improvement. Basically, geo-fiber or geotextile and geogrid be influenced by their physical effects are used to improve soil properties. Soil strengthening by natural or 
synthetic fiber is considered an efficient ground improvement technique to improve strength and stability of poor or expansive soil due to cost effectiveness, eco-friendly, easy adaptability and reproducibility. As a result, these are attracted the attention of researchers globally. Most common types of natural fibers are coir, cotton, sisal, bamboo jute, straw, sugarcane and hair whereas the synthetic fibers are nylon, polypropylene, polyester, polyethylene and glass fiber. Soil improvement with nylon fibers could be profitable because it is promising to use nylon fibers as another small cost material for soil reinforcement [43]. A number of research studies on fiber-reinforced soils have been carried out recently using tri-axial compression tests [43-45], unconfined compression test [46, 47], CBR test [47-51], direct shear test [52, 53,47], tensile strength test [46] and fiber pullout test [54]. Fiber strengthened soil works as a composite material in which fibers of moderately high tensile strength are entrenched in a matrix of soil. The key necessities of the strengthening materials are strength, stability, easy to treatment, high devotion or friction with soil and accessibility at small cost $[55,56]$. The simple mechanism of strengthened soil consists of originating of frictional forces between the clay particles and reinforcing materials. By means of friction the clay allocations the forces produced in soil mass to the strengthening materials hence developed tension. The soil produces quasi cohesion on the route in which reinforcing material is positioned and the cohesion is proportionate to tension generated in reinforcement. Shear stresses in the soil mobilize tensile resistance in the fibers, which in turn conveys better strength to the weak soil $[44,48-51,57-60]$.

Moreover, it can be method of chemical and physical stabilization combinedly, for instance, work with RHA and nylon fiber together. RHA works as stabilizing agent and nylon fiber works as reinforcement. Stabilized and strengthened soils are in a common sense, amalgamated substances that outcome from the combination and optimization of the properties of independent constituent materials. The main objectives of soil stabilization are to progress on-site materials to make a solid and strong subbase and base courses $[42,61]$ and to drop the whole project expense by making best use of locally accessible resources $[50,59]$. Soil stabilization improve the various engineering properties of the stabilized soil such as increase soil bearing capacity, strength, durability stiffness, and reduction in settlement, soil plasticity and swelling/ shrinkage $[36,62-64]$. The soil stabilization is being used to the maximum variety of engineering works. The most common application being used in the construction of foundations, pavements, retaining walls, cement walls or boundary to reduce the construction cost.

Muntohar [19] used lime, RHA and plastic fiber and investigated that lime and RHA mixed stabilized soil increase UCS value more than 2.4 times that of untreated soil. When he included plastic fiber into lime and RHA mixed soil, UCS, tensile strength, stiffness upsurges considerably with increase of plastic fiber percentage and fiber length. He suggested that most effective plastic fiber length is in the range between 20 and $40 \mathrm{~mm}$ corresponding to the fiber quantities. Roy [65] used different proportions of RHA and a slight quantity of cement for soil stabilization. He investigated that OMC increases but MDD decreases due to increase in proportion of RHA. In addition, UCS and CBR test value of stabilized soil are significantly enhanced with RHA dosages. Khan et al. [66] investigated the impact of various proportions of nylon fiber on compaction and soaked CBR test value of fly ash treated expansive soil. Rajan and Subrahmanyam [67] used RHA and lime for stabilization of expansive soil and investigated shear strength and consolidation characteristics. He observed that RHA acts as a pozzolanic substance when use it as minor stabilizer beside with lime and cement. It increases the strength properties of expansive soil. He also found that RHA mixed stabilized soil offer low strength under soaked condition and combined effect of RHA and lime decreases the compression index. Ramadhansyah et al. [68] studied the UCS value of concrete over different fineness of RHA substituting cement up to $15 \%$. He observed that the UCS value of concrete improve significantly. Kumar and Tabor [57] investigated the strength properties of silty clay with nylon fiber for varying degrees of compaction. Punthutaecha et al. [69] used nylon and polypropylene as reinforcement and fly ash as pozolonic material. He investigated the single and mutual effect of these stabilizing agent on volume change manners of expansive soil. Sharma [70] studied impact of replacement of cement with RHA on UCS value of concrete using super plasticizer and plastic fibers. He observed that up to $10 \%$ of cement can be substitute with RHA in plastic fiber mixed soil because it gives almost the same UCS value. Sabat [71] investigated the impact of polypropylene fiber on engineering properties of RHA-lime mix stabilized expansive soil. He observed that the addition of RHA and Lime decreases the MDD and upsurges the OMC of the expansive soil. In contrast, MDD goes on declining and OMC goes enhancing with increase in polypropylene fiber content in RHA-lime mix stabilized expansive soil. Inclusion of different content of polypropylene fiber in RHA-lime mixed stabilized soil increases the UCS and soaked CBR values of the expansive soil. Sabat and Pradhan [72] investigate the effects of fly ash stabilized soil with polypropylene fiber as reinforcement (both content and length) on compaction properties, UCS, soaked CBR and swelling pressure. Jain and Jain [73] used nylon fiber and stone dust as stabilizing agent and investigated that addition of $3 \%$ nylon fiber with $20 \%$ stone dust decreases 
the swelling pressure about $48 \%$. He also observed that inclusion of randomly distributed nylon fiber in stone dust stabilized expansive soil increases ultimate bearing capacity and decreases settlement.

This research presents the impact of RHA and nylon fiber on strength characteristics of poor organic soil in south-west part of Bangladesh. In order to investigate the effect of RHA and nylon fiber on poor or weak organic soil, series of test such as standard proctor compaction test, UCS test, soaked and unsoaked CBR test are conducted first on the soil samples partially replaced by RHA with dosage $0 \%, 5 \%, 10 \%, 15 \%, 20 \%$ and then soil plus optimum percent of RHA and different content of nylon fiber $(0.3 \%, 0.5 \%, 0.7,1.0 \%, 1.2 \%)$. The experimental standard proctor compaction, UCS, unsoaked and soaked CBR values of different content of RHA stabilized soil and different percent of nylon fiber plus optimum percentage of RHA mixed soil were compared with untreated poor organic soil.

\section{Materials and methods used}

\subsection{Collection of samples}

The soil sample was collected from the side of Civil Engineering Building, Khulna University of Engineering and Technology (KUET), Khulna, Bangladesh whose latitude is $22^{\circ} 90.031^{\prime} \mathrm{N}$ and longitude is $89^{\circ} 50.296^{\prime} \mathrm{E}$. It was taken at a depth of around $2 \mathrm{~m}$ from the standing earth surface by manual excavation. The Rice Husk was collected from a rice mill in front of the Govt. Laboratory High School, Khulna, Bangladesh. The Nylon fiber was collected from the Fulbarigate Bazar, Khulna, Bangladesh.

\subsection{Rice husk ash (RHA)}

Husk is known as a byproduct produced by rice mill. Almost $78 \%$ weight of paddy is received as broken rice and bran during milling process. Rest of $22 \%$ by paddy weight is generated as husk [74]. This husk is used as fuel in the rice mills to produce steam for the parboiling method. This husk comprises around $75 \%$ organic instable substance. Nearly $25 \%$ of husk weight is converted into ash through the firing process, is called RHA [75]. About $220 \mathrm{kgs}$ (22\%) of husk is produced from every $1000 \mathrm{kgs}$ of paddy by milling process. When this rice husk is burnt in the boilers, about $55 \mathrm{kgs}(25 \%)$ of RHA is generated. It is considered as a valueless or waste material $[8,36]$. It is a carbon neutral green product and super pozzolanic material. The non-crystalline silica and high
Table 1 Physical properties of RHA

\begin{tabular}{lll}
\hline Serial No. & Particulars & Properties \\
\hline 1 & Color & Gray \\
2 & Shape-texture & Irregular \\
3 & Odour & Odourless \\
4 & Appearance & Very fine \\
5 & Specific gravity & 2.18 \\
6 & Mean particle size $(\mu \mathrm{m})$ & 12.34 \\
7 & Passing \# 325 $(\%)$ & 96.6 \\
\hline
\end{tabular}

Table 2 Chemical compositions of RHA

\begin{tabular}{llc}
\hline Serial No. & Particulars & Properties \\
\hline 1 & Silicon dioxide (\%) & 89.02 \\
2 & Potassium oxide (\%) & 2.29 \\
3 & Calcium oxide (\%) & 0.54 \\
4 & Magnesium oxide (\%) & 0.38 \\
5 & Aluminum dioxide (\%) & 0.21 \\
6 & Sodium oxide (\%) & 0.8 \\
7 & Iron oxide (\%) & 0.23 \\
8 & Loss on ignition (LOI) (\%) & 5.91 \\
\hline
\end{tabular}

specific surface area of the RHA are mainly responsible for its high pozzolanic reactivity. This super-pozzolana can be used in a huge way to make special concrete mixes. Due to contain high proportion of fine amorphous silica, RHA is in highly demand in the manufacture of special cement and concrete mixed, high performance concrete, high strength, low permeability concrete for use in bridges, harbors, embankments, barrages, marine environments, nuclear power plants port structures and so on. RHA contribute to excellent stability and load bearing capacity. In this research, collected rice husk was burnt at $6500^{\circ} \mathrm{C}$ temperature for $1 \mathrm{~h}$. As received ash was sieved for $15 \mathrm{~min}$. Physical and chemical properties of RHA are given in Tables 1 and 2 respectively.

\subsection{Nylon fiber}

Nylon is a general description for a lineage of synthetic polymers, based on aliphatic or semi-aromatic polyamides. It is thermoplastic silky materials that can be meltprocessed into fibers, films or shapes. Nylon fibers are used as the reinforcement in this work. It is not affected by the existence of salts in earths, biological degradation and ultraviolet degradation [43]. Tensile strength of nylon fiber is better than lot of the other substances such as paper and rubber from used tires [47]. Physical properties of nylon fiber are given in Table 3. 
Table 3 Physical properties of nylon fiber (collected from manufacturer)

\begin{tabular}{lll}
\hline Serial No. & Particulars & Properties \\
\hline 1 & Tensile strength $(\mathrm{MPa})$ & 920 \\
2 & Yield strength $(\mathrm{MPa})$ & 27 \\
3 & Specific gravity $\left(\mathrm{g} / \mathrm{cm}^{3}\right)$ & 1.10 \\
4 & Tenacity dry $(\mathrm{gm} / \mathrm{den})$ & 6 \\
5 & Tenacity wet $(\mathrm{gm} / \mathrm{den})$ & 4.5 \\
6 & Yong's modulus $(\mathrm{MPa})$ & 5170 \\
8 & Ultimate elongation $(\%)$ & 16.20 \\
9 & Resiliency & Excellent \\
10 & Dimensional stability & Good \\
11 & Hand feel & Soft and smooth \\
\hline
\end{tabular}

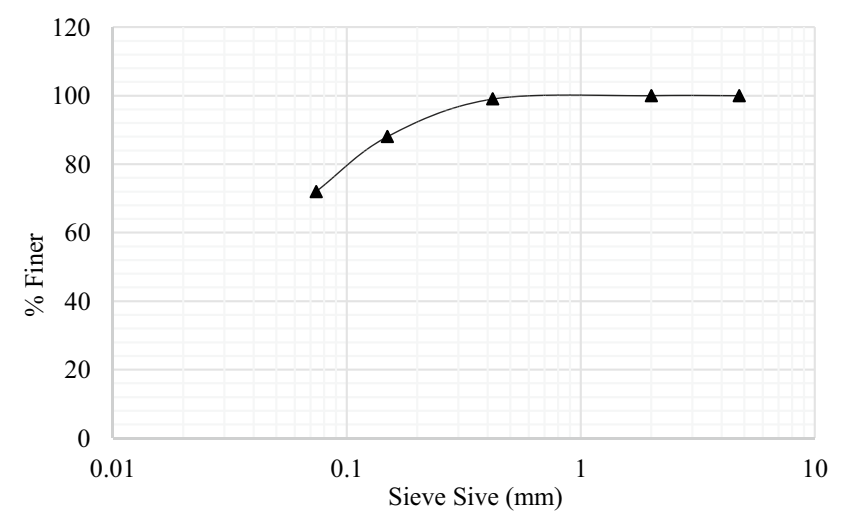

Fig. 1 Grain size distribution curve for soil

\subsection{Experimental program}

The collected soil was taken in the geotechnical engineering laboratory and expanded over the floor to get air dry. Following the step, this dry soil was squeezed and crused by using a manual hammer as fine as possible. The soil powder was passed through a standard sieve of $4.75 \mathrm{~mm}$ opening before equipping the specimens for lab test. In test series-I, physical and different index properties of untreated organic soil in terms of moisture content, Specific gravity, Atterberg limit, grain size distribution, organic content, $\mathrm{pH}, \mathrm{UCS}$ value, compaction parameters were determined for untreated organic soil. Specific gravity test and Atterberg limit tests were conducted according to ASTM D854-14 [76] and ASTM D-4318-00 [77] respectively. $\mathrm{pH}$ test was conveyed according to ASTM D2976-15 [78]. Grain size distribution test was performed according to ASTM E112-13 [79]. The grain size distribution curve is displayed in Fig. 1. Ignition test was conducted to determine organic content in soil. At first, $5 \mathrm{~g}$ air-dried soil sample was taken in a crucible and heated at $105^{\circ} \mathrm{C}$ for $2 \mathrm{~h}$. After that dry soil was weighted to get dry weight and then heated again at $360^{\circ} \mathrm{C}$ for $2 \mathrm{~h}$. Following the step, it was cooled to less than $150^{\circ} \mathrm{C}$ and weighted again. Typical engineering properties of soil samples are given in Table 4 .

In test series-II, the samples were prepared by mixing poor organic soil with different percentage of RHA $(0 \%$, $5 \%, 10 \%, 15 \%$ and $20 \%$ ) and after that a series of laboratory test such as standard proctor compaction test, UCS test, soaked and unsoaked CBR test were conducted. In
Table 4 Engineering properties of soil sample

\begin{tabular}{|c|c|c|}
\hline Serial numbers & Name of the experiment & Experimental results \\
\hline 1. & Specific Gravity & $\mathrm{G}_{\mathrm{S}}=2.50$ \\
\hline 2. & Natural water content, W (\%) & $W=74.28 \%$ \\
\hline \multirow[t]{3}{*}{3.} & Atterberg's limit test & \\
\hline & Liquid limit, $\mathrm{W}_{\mathrm{L}}(\%)$ & $W_{L}=89.38 \%$ \\
\hline & Plasticity index, $I_{P}(\%)$ & $\mathrm{I}_{\mathrm{P}}=37.09 \%$ \\
\hline \multirow[t]{3}{*}{4.} & Sieve analysis & Sand $\%(4.75-0.076 \mathrm{~mm})=3.33 \%$ \\
\hline & & Silt $\%(0.076-0.002 \mathrm{~mm})=35.75 \%$ \\
\hline & & Clay $\%(<0.002$ to $>0.001 \mathrm{~mm})=60.92 \%$ \\
\hline 5. & Organic content (\%) & $O C=20.09 \%$ \\
\hline 6. & $\mathrm{pH}$ & 6.06 \\
\hline \multirow[t]{3}{*}{7.} & Compaction test & \\
\hline & Maximum dry density (MDD), $\left(\mathrm{kN} / \mathrm{m}^{3}\right)$ & $\mathrm{MDD}=16.66 \mathrm{kN} / \mathrm{m}^{3}$ \\
\hline & Optimum moisture content (OMC), (\%) & $\mathrm{OMC}=12.23 \%$ \\
\hline \multirow[t]{4}{*}{8.} & Unconfined compression test (UCS) & $\mathrm{UCS}=42.02 \mathrm{kPa}$ \\
\hline & Classification & \\
\hline & USCS & $\mathrm{OH}$ \\
\hline & AASHTO & \\
\hline
\end{tabular}


test series-III, different percentage of nylon fibers $(0.3 \%$, $0.5 \%, 0.7 \%, 1.0 \%$, and $1.2 \%$ ) were added in optimum percent of RHA mixed soil and then again, a series of laboratory test including standard proctor compaction test, UCS test, soaked and unsoaked CBR test were performed. In all cases, test samples were taken into a polyethylene bag and continuous mixing was done by trembling, turn over, and wring the bag to pass out the air from the spaces in soil.

Compaction is the method of densification of soil by reducing air voids. The degree of compaction of a given soil is measured in terms of its dry density. The dry density value of a given soil sample is maximum at its optimum moisture content. Standard proctor compaction tests were performed according to ASTM D 698 [80] to determine compaction parameters (MDD and OMC) of untreated organic soil, soil-RHA and soil-RHA-Fiber mixture. In each case mould of diameter $100 \mathrm{~mm}$ and height $127.3 \mathrm{~mm}$ was used and specimens were compacted in three equal layers by hammer of weight $2.5 \mathrm{~kg}$ and free fall of $315 \mathrm{~mm}$. Special care was taken for the stabilized specimens. Dry density versus water content was plotted in a graph. The MDD and OMC were found from dry density and moisture content relationship. Dry density against water content graph for different percent of RHA treated soil and soilRHA (optimum dosage)-fiber mixture is shown in Figs. 2 and 7 respectively.

UCS test is conducted in most of the geotechnical engineering projects to verify the effectiveness of soil. To determine UCS value of untreated organic soil $(0 \%$ $\mathrm{RHA})$, different percentage of RHA (5-20\%) treated organic soil and soil-RHA-fiber mixed soil, cylindrical samples (diameter of $38 \mathrm{~mm}$ and height of $76 \mathrm{~mm}$ ) were used. Test samples were equipped at its corresponding OMC and MDD by stationary compaction in UCS mould. These specimens were tested in a compression testing machine with strain rate of $1.25 \%$ per minute till failure of the sample. The unconfined compressive strength

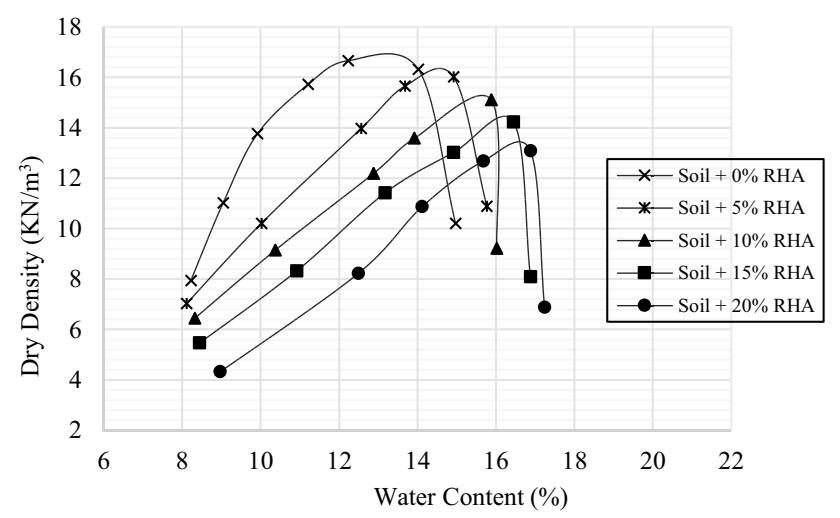

Fig. 2 Dry density versus water content graph for different percent of RHA treated soil of the soil samples was assessed according to ASTM D-2166-06 [81]. The relationship of deviator stress and axial strain were plotted in a graph. From the relationship of deviator stress and axial strain, UCS values were determined. Deviator stress versus axial strain curves graph for different percent of RHA treated soil and soilRHA (optimum dosage)-fiber mixture is shown in Figs. 4 and 9 respectively.

CBR is one of the most important parameters, used in the assessment of soil subgrades for both rigid and flexible pavements design. For this test, cylindrical specimens were prepared corresponding to their MDD at OMC in a rigid metallic cylindrical mould having an inside diameter of $150 \mathrm{~mm}$ and a height of $175 \mathrm{~mm}$ and compacted with 5 layers by 56 blows. Upper surface of the test specimen in the CBR mould was shaped flat and a strainer paper and a crannied metallic disc were installed over the specimen. Next step, about a $5 \mathrm{~kg}$ surcharge weight was positioned on the surface of the compacted samples. CBR values were determined for both unsoaked and soaked condition. To determine CBR value in soaked conditions, CBR mould with test samples were placed in a water container for soaking. After $96 \mathrm{~h}$ (i.e. 4 days) of soaking, all the CBR mould was taken out from water container and the top surface of specimen was left exposed to air for half an hour. Soaked and unsoaked sample with CBR mould were taken under a motorized loading frame for testing. A strain rate of $1.20 \mathrm{~mm} / \mathrm{min}$ was used for all the tests, and same working procedure was followed for all specimens. A number of soaked and unsoaked CBR tests were conducted on untreated organic soil, soil-RHA and soil-RHA-fiber mixture according to ASTM D1883-16 [82]. CBR test values (soaked and unsoaked) for different percent of RHA treated soil and soil-RHA-fiber mixture is shown in Tables 7 and 10 respectively.

\section{Results and discussions}

A series of laboratory test such as standard proctor compaction test, $C B R$ test, soaked and unsoaked CBR test were conducted first on untreated organic soil ( $0 \%$ RHA) and then soil samples partially replaced by RHA with dosage $5 \%, 10 \%, 15 \%, 20 \%$. Optimum percentage of RHA was determined from UCS test. After that a series of test including UCS test, standard proctor compaction test, soaked and unsoaked CBR test were performed on sample prepared by random addition of nylon fibers with dosage $0.3 \%, 0.5 \%, 0.7,1.0 \%, 1.2 \%$ (by dry weight) in optimum content (15\%) of RHA (by dry weight) treated soil. The interpretation of tests results has been discussed in the following sections. 
Table 5 MDD and OMC value for different content of RHA treated soil

\begin{tabular}{|c|c|c|c|c|}
\hline \multirow{2}{*}{$\begin{array}{l}\text { Mix pro- } \\
\text { portion: } \\
\text { (soil + \% } \\
\text { RHA) }\end{array}$} & \multicolumn{4}{|c|}{ Standard proctor compaction test } \\
\hline & $\begin{array}{l}\text { MDD val- } \\
\text { ues (kN/ } \\
\left.\mathrm{m}^{3}\right)\end{array}$ & $\%$ Decreases & $\begin{array}{l}\text { OMC values } \\
(\%)\end{array}$ & $\%$ Increases \\
\hline $\begin{array}{l}\text { Soil + 0\% } \\
\text { RHA }\end{array}$ & 16.66 & - & 12.23 & - \\
\hline $\begin{array}{l}\text { Soil + 5\% } \\
\text { RHA }\end{array}$ & 16.02 & 3.84 & 14.92 & 21.99 \\
\hline $\begin{array}{l}\text { Soil }+10 \% \\
\text { RHA }\end{array}$ & 15.11 & 9.30 & 15.88 & 29.84 \\
\hline $\begin{array}{l}\text { Soil }+15 \% \\
\text { RHA }\end{array}$ & 14.22 & 14.65 & 16.45 & 34.51 \\
\hline $\begin{array}{c}\text { Soil }+20 \% \\
\text { RHA }\end{array}$ & 13.08 & 21.49 & 16.88 & 38.02 \\
\hline
\end{tabular}

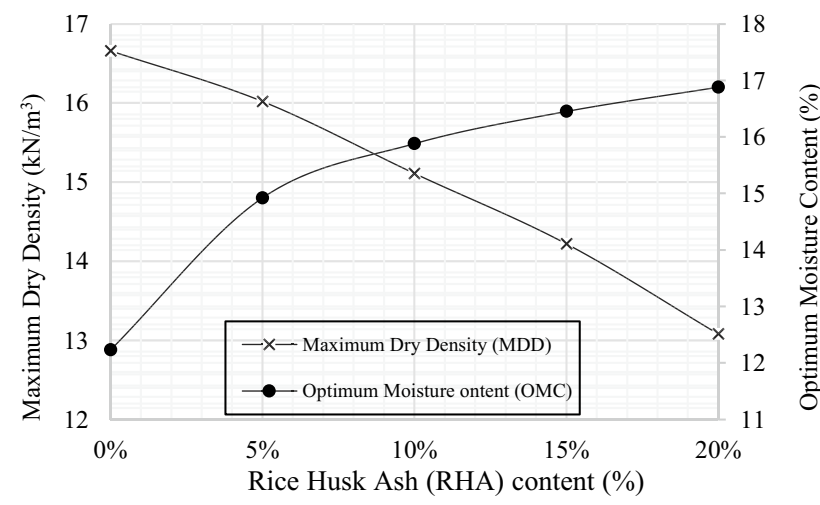

Fig. 3 Variation of MDD and OMC for different percentage of RHA

\subsection{Impact of RHA on compaction parameters of organic soil}

Dry density versus water content diagram for various percentage of RHA (0-20\%) treated soil is shown in Fig. 2. MDD and OMC value for different dosage of RHA treated soil are listed in Table 5. Variation of MDD and OMC for different proportion of RHA in organic soil are shown in Fig. 3. As per the data expressed in the Table 5 and the Fig. 3 , it can be undoubtedly said that the MDD diminishes but OMC upsurges regularly with increase in different dosage of RHA in organic soil. The MDD value decreases from 16.66 to $13.08 \mathrm{kN} / \mathrm{m}^{3}$ whereas the OMC enhances from 12.23 to $16.88 \%$. Parallel trends in OMC and MDD were reported by several previous studies (e.g. [8, 20, 40, 72, 83, 84]).

The decrease in the MDD can be ascribed to the replacement of organic soil by the RHA in the mix. This is owing to relatively poor specific gravity of RHA (2.18) than the specific gravity value of replaced soil (2.50) and another

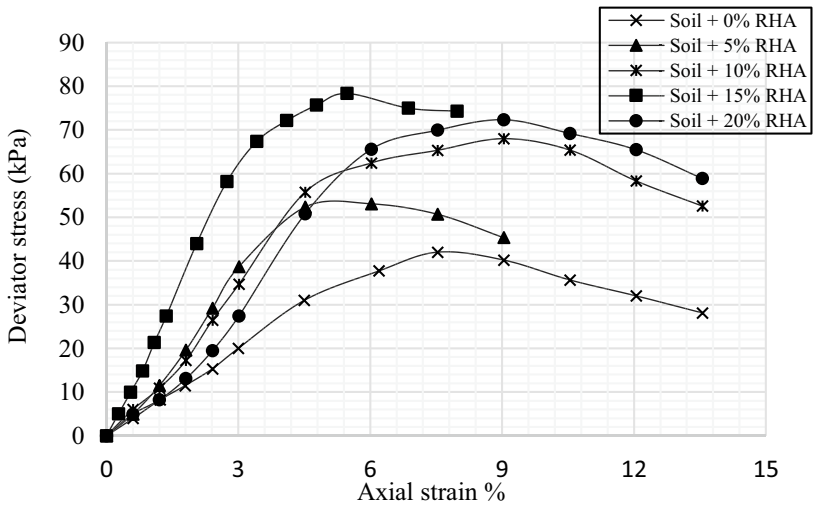

Fig. 4 Load deflection curve for different percentage of RHA stabilized soil

Table 6 The UCS values of the soil mixed with RHA

\begin{tabular}{lll}
\hline $\begin{array}{l}\text { Mix proportion: } \\
\text { (soil + \% RHA) }\end{array}$ & UCS values (kPa) & $\begin{array}{l}\text { Percentage } \\
\text { increases (\%) }\end{array}$ \\
\hline Soil + 0\% RHA & 42.02 & - \\
Soil + 5\% RHA & 53.07 & 26.30 \\
Soil + 10\% RHA & 67.99 & 61.80 \\
Soil + 15\% RHA & 78.33 & 86.41 \\
Soil + 20\% RHA & 72.32 & 72.11 \\
\hline
\end{tabular}

reason may be the preliminary synchronous flocculation and agglomeration of soil Particles due to cation interchange. In contrast, the OMC of stabilized soil increases as percentage of RHA increases. This is due to the real fact that the RHA particles are hollow and they require more water for their absorption and well lubrication.

\subsection{Impact of RHA on UCS value of organic soil}

Load deflection curve for organic soil mixed with different Percentage of RHA is displayed in Fig. 4. The UCS test results for different percentage of RHA treated soils are listed in Table 6. Variation of UCS values for different content of RHA stabilized soil is shown in Fig. 5. As per the data revealed in the Table 6 and the Fig. 5 , it can be clearly seen that the UCS value is gradually increases at initial stage due to increase of different dosages of RHA in organic soil. After reaching at the highest point, UCS value is found to decrease due to increase in RHA dosages. The considerable increment in UCS value is about $78.33 \%$ at $15 \%$ replacement of poor organic soil by RHA. The optimum RHA dosage corresponding to highest UCS value is initiated to be $15 \%$. In previous studies, similar strength improvement was described by some researchers (e.g. [8, 40, 72, 83-85]).

The reason of such kind of action is due to inclusion of RHA, the angle of internal friction of soil increases, thus the 


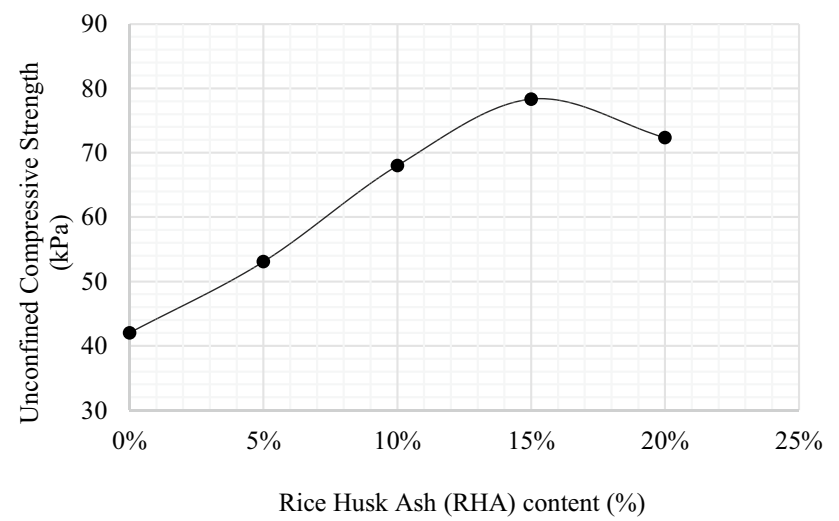

Fig. 5 Variation of UCS for different content of RHA

soil gets more shear strength owing to increase in angle of internal friction in addition to the attachment of organic soil this is observed as increase in value of UCS test. The strength decreases due to inclusion of excessive dosages of RHA (above 1.0\%), as the interconnection of soil reduces due to diminution in clay content.

\subsection{Impact of RHA on CBR value of organic soil}

Soaked and unsoaked CBR test results for different percentage of RHA stabilized soil are recorded in Table 7. Variation of soaked and unsoaked CBR value for different proportion of RHA treated soil are displayed in Fig. 6. As the dosage of RHA increases, unsoaked and soaked CBR values of RHA-soil mixture also increases initially up to $15 \%$ replacement of organic soil and then decreases. There is a considerable increment in soaked and unsoaked CBR value about $4.48 \%$ and $6.67 \%$ respectively at $15 \%$ replacement of untreated organic soil by RHA. The investigated results in the present study were parallel to previous findings (e.g. [20, 84].

The increment in soaked and unsoaked CBR value after inclusion of different percentage of RHA is due to the formation of cementing agents due to Pozzolanic reactions by the addition of silica in the RHA. The decrement in soaked and unsoaked CBR value after 15\% RHA may be due to surplus RHA that could not be not mobilized in

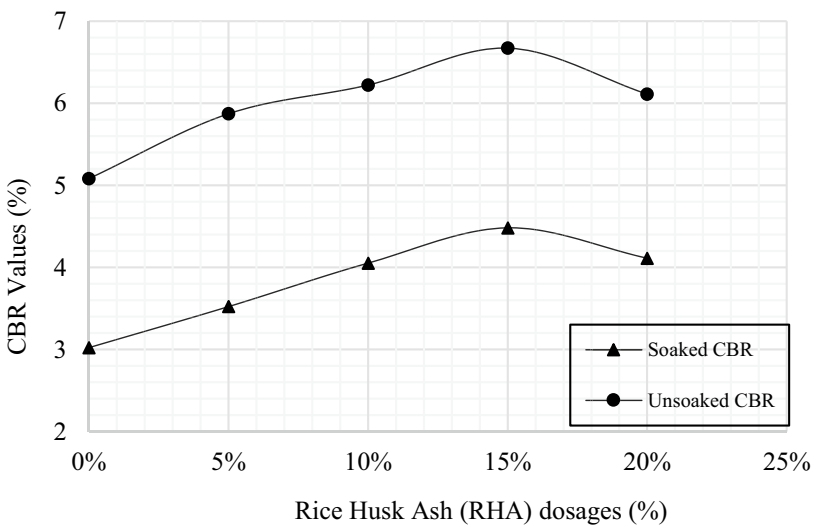

Fig. 6 Variation of CBR values of soil mixed with different dosages of RHA

the reaction, which consequently occupies spaces within the sample and hence decreasing bond in the soil-RHA mixtures.

\subsection{Impact of RHA plus nylon fiber on compaction parameters of organic soil}

Dry density versus water content graph for inclusion of different percentage $(0.3-1.2 \%)$ of nylon fiber in $15 \%$ (optimum dosage) RHA stabilized soil is shown in Fig. 7. The MDD and OMC values for different percent of nylon fiber and 15\% RHA plus soil are listed in Table 8. Variation of MDD and OMC value for inclusion of different percentage of nylon fiber into optimum percent RHA treated soil are shown in Fig. 10. From the Table 8 and Fig. 8 , it is clearly seen that the MDD decreases but OMC increases gradually due to inclusion of different percent of nylon fiber content into 15\% RHA stabilized soil. The MDD decreases from 12.52 to $9.47 \mathrm{kN} / \mathrm{m}^{3}$ whereas the OMC increases from 17.22 to $21.47 \%$ for inclusion of different percentage $(0.3-1.2 \%)$ of nylon fiber in 15\% RHA treated soil. This phenomenon was also observed by some researchers with pozolonic materials and natural/geosynthetic fiber stabilized soil, for instances: Sabat and Pradhan [72], Ramesh and Kumar [83].
Table 7 Soaked and unsoaked CBR values for RHA treated soil

\begin{tabular}{lllll}
\hline $\begin{array}{l}\text { Mix proportion } \\
\text { (soil + \% RHA) }\end{array}$ & Soaked CBR (\%) & $\begin{array}{l}\text { Percentage } \\
\text { increases (\%) }\end{array}$ & $\begin{array}{l}\text { Unsoaked CBR } \\
(\%)\end{array}$ & $\begin{array}{l}\text { Percentages } \\
\text { increases (\%) }\end{array}$ \\
\hline Soil + 0\% RHA & 3.02 & - & 5.08 & - \\
Soil + 5\% RHA & 3.52 & 16.56 & 5.87 & 15.55 \\
Soil + 10\% RHA & 4.05 & 34.11 & 6.22 & 22.44 \\
Soil + 15\% RHA & 4.48 & 48.35 & 6.67 & 31.29 \\
Soil + 20\% RHA & 4.11 & 36.09 & 6.11 & 20.28 \\
\hline
\end{tabular}




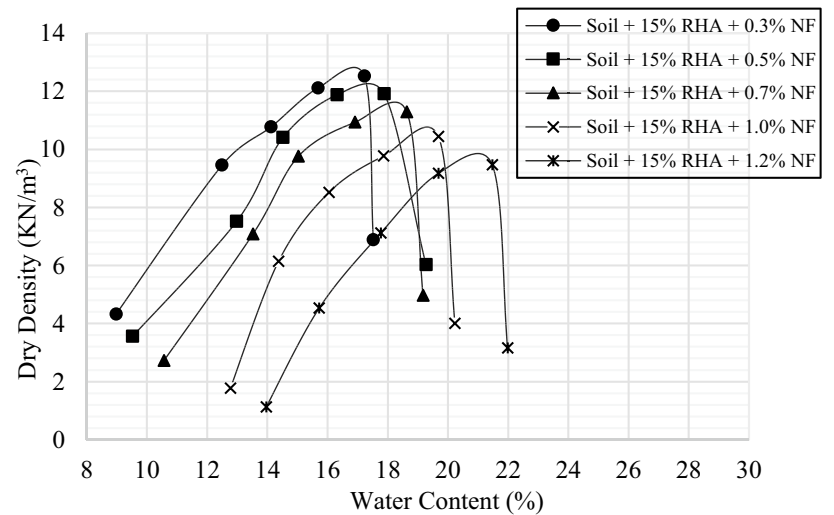

Fig. 7 Dry density versus water content graph for addition of different dosages of nylon fiber in 15\% RHA Plus soil mixture

This is due to the fact that different dosages of nylon fiber in 15\% RHA treated soil replace more volume of soil. Here RHA and nylon fiber, both the materials have low densities. Hence the MDD values are greatly reduced by increase in percent of reinforced material (nylon fiber) in the composite mix. The increase of moisture content is also imputed by the pozzolonic reaction of RHA with the clay particles. Some fibers, especially nylon fiber absorb water which may help to increase the OMC value (Table 9).

\subsection{Impact of RHA plus nylon fiber on UCS value of organic soil}

Load deflection curves for addition of different dosages of nylon fiber into $15 \%$ RHA (optimum percent) plus soil mixture are shown in Fig. 9. Variation of UCS values for different percentage of nylon fiber in optimum dosage of RHA treated soil is shown in Fig. 10. It is observed that there is a significant increase in UCS value due to the inclusion of nylon fiber in organic soil treated with optimum percentage of RHA (15\%). The UCS value of RHA stabilized soil increases with increase in nylon fiber dosages up to $1.0 \%$ and thereafter it decreases due to inclusion of nylon fiber content. The maximum UCS value is found $148.11 \mathrm{kPa}$ for $1.0 \%$ nylon fiber in $15 \%$ RHA stabilized soil. The parallel

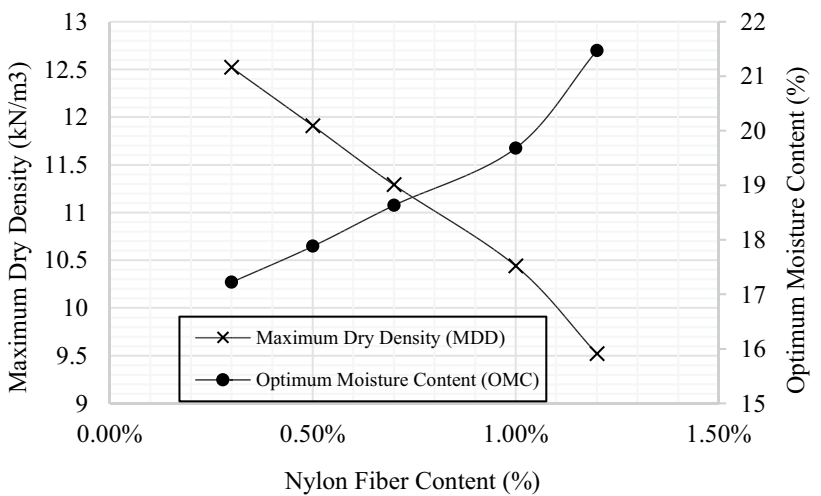

Fig. 8 Variation of MDD and OMC for inclusion of different percentage of nylon fiber in 15\% RHA treated soil

Table 9 The UCS values for soil mixed with optimum dosage of $\mathrm{RHA}$ and nylon fiber

\begin{tabular}{lll}
\hline $\begin{array}{l}\text { Mix proportion: (soil + 15\% } \\
\text { RHA + \% NF) }\end{array}$ & UCS values (kPa) & $\begin{array}{l}\text { Percentage } \\
\text { increases (\%) }\end{array}$ \\
\hline Soil + 15\% RHA + 0.3\% NF & 88.70 & - \\
Soil + 15\% RHA + 0.5\% NF & 101.19 & 14.08 \\
Soil + 15\% RHA + 0.7\% NF & 122.4 & 37.92 \\
Soil + 15\% RHA + 1.0\% NF & 148.11 & 66.98 \\
Soil + 15\% RHA + 1.2\% NF & 135.61 & 52.89 \\
\hline
\end{tabular}

experimental outcomes have also been presented by previous investigators [71, 72].

Inclusion of arbitrarily oriented distinct nylon fiber into coarse materials, increase its load deformity manners by cooperating with clay particles mechanically through surface friction as well by dovetailing. The connection and dovetailing between coarse materials and strengthening enables the transfer of tensile strain generated in the soil mass to the reinforcement and therefore, the tensile strength of the strengthening material is mobilized and aids in increasing the load bearing capability of the reinforced mass. Moreover, chemical reactions start when RHA is mixed with the soil particles consist of pozzolanic reactions, cation interchange, carbonation and cementation.
Table 8 MDD and OMC values for different content of nylon fiber in 15\% RHA treated soil

\begin{tabular}{lllll}
\hline $\begin{array}{l}\text { Mix proportion: (soil + \% } \\
\text { RHA + \% NF) }\end{array}$ & \multicolumn{4}{l}{ Standard proctor compaction test } \\
\cline { 2 - 5 } & $\begin{array}{l}\text { MDD values } \\
\left(\mathrm{kN} / \mathrm{m}^{3}\right)\end{array}$ & \% Decreases & OMC values (\%) & \% Increases \\
\hline Soil + 15\% RHA + 0.3\% NF & 12.52 & - & 17.22 & - \\
Soil + 15\% RHA + 0.5\% NF & 11.91 & 4.87 & 17.88 & 3.83 \\
Soil + 15\% RHA + 0.7\% NF & 11.29 & 9.82 & 18.63 & 8.19 \\
Soil + 15\% RHA + 1.0\% NF & 10.44 & 16.61 & 19.68 & 14.29 \\
Soil + 15\% RHA + 1.2\% NF & 9.47 & 24.36 & 21.47 & 24.68 \\
\hline
\end{tabular}




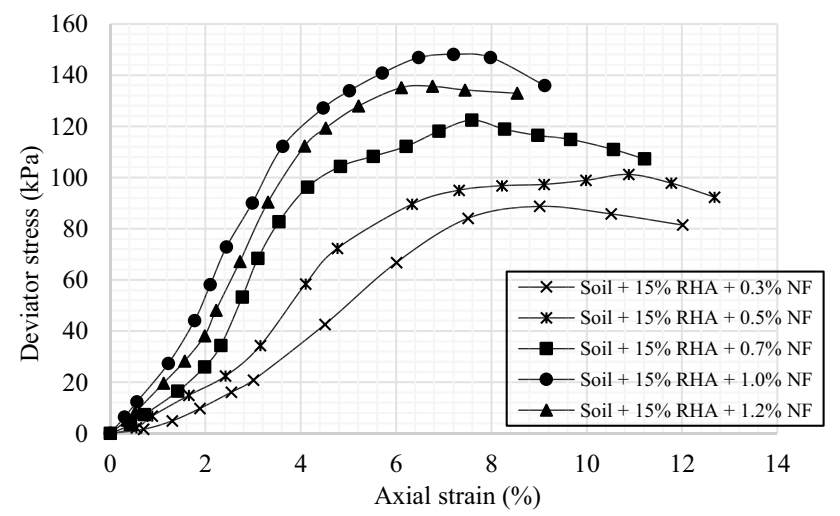

Fig. 9 Load deflection curve for different dosages of nylon fiber in $15 \%$ RHA Plus soil mixture

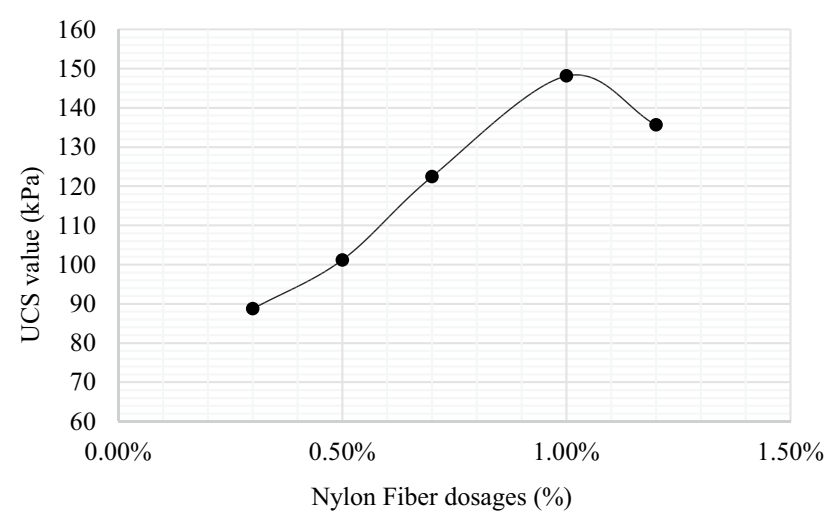

Fig. 10 Variation of UCS values for different content of nylon fiber in $15 \%$ RHA stabilized soil

These result in agglomeration in huge shaped particles. This may cause UCS value of fiber-ash treated soil is experienced greater than untreated organic soil. UCS value goes on diminishing beyond $1.0 \%$ of nylon fiber dosages because of unnecessary fiber quantity, the interaction between the RHA mixed soil and fibers are bothered and inadequate clay particles are not competent to incur the large proportion of nylon fibers. The most applicable proportion of nylon fiber corresponding to the result of maximum UCS is observed to be $1.0 \%$ by waterless unit weight of plain organic soil sample.

\subsection{Impact of RHA plus nylon fiber on CBR value of organic soil}

Soaked and unsoaked CBR value for different dosage of nylon fiber in optimum percentage of RHA (15\%) mixed soil are listed in Table 10. As per the data revealed in the Table 10 and the Fig. 11, it can be said without any doubt that unsoaked and soaked CBR test value enhances gradually due to addition of different proportion of nylon fiber into 15\% RHA and soil mix. However, this increment trend is broken beyond $1.0 \%$ of nylon fiber dosages into $15 \%$ RHA treated soil. The considerable unsoaked and soaked CBR test results are found $16.03 \%$ and $7.83 \%$ respectively for $1.0 \%$ nylon fiber in 15\% RHA stabilized soil. The optimum nylon fiber dosages corresponding to highest soaked and unsoaked CBR test value is found to be $1.0 \%$. Parallel trend was observed by some researchers with the natural and geo-synthetic fiber strengthened soil and pozolanic materials, for instances: Singh [60], Sabat and Pradhan [72], Gupta and Kumar [84].

The unsoaked and soaked CBR value increases due to existence of nylon fiber in soil-RHA mixture. Nylon fibers have high tensile strength ( $920 \mathrm{MPa}$ ) and acts like strong reinforcement in soil-RHA mixture. A mechanical bonding generates between RHA mixed soil and nylon fiber. This may the real reason behind the increment of unsoaked and soaked CBR value. Soaked and unsoaked CBR value goes on decreasing beyond $1.0 \%$ of nylon fiber due to higher fiber proportion the interaction between the RHA-soil and fiber is bothered and inadequate soil particles have no ability to bind the extra content of nylon fibers. The most applicable proportion of nylon fiber corresponding to the maximum CBR value is found $1.0 \%$ by dry weight of untreated organic soil sample.

\section{Conclusion}

Industrial waste RHA and nylon fibers have made significant impact on the stability properties of poor organic soil of south-west part of Bangladesh. Based on the results of different tests in this research work, the following conclusions could be drawn.
Table 10 CBR value for different content of nylon fiber in $15 \%$ RHA treated soil

\begin{tabular}{lllll}
\hline Mix proportion (soil + 15\% RHA+ \% NF) & Soaked CBR (\%) & $\begin{array}{l}\text { Percentage } \\
\text { increases (\%) }\end{array}$ & $\begin{array}{l}\text { Unsoaked } \\
\text { CBR (\%) }\end{array}$ & $\begin{array}{l}\text { Percentages } \\
\text { increases (\%) }\end{array}$ \\
\hline Soil + 15\% RHA + 0.3\% nylon fiber & 5.11 & - & 8.22 & - \\
Soil + 15\% RHA + 0.5\% nylon fiber & 5.92 & 15.85 & 10.97 & 33.45 \\
Soil + 15\% RHA + 0.7\% nylon fiber & 6.96 & 36.20 & 13.88 & 68.86 \\
Soil + 15\% RHA + 1.0\% nylon fiber & 7.83 & 53.23 & 16.03 & 95.01 \\
Soil + 15\% RHA + 1.2\% nylon fiber & 7.22 & 41.29 & 15.49 & 88.44 \\
\hline
\end{tabular}




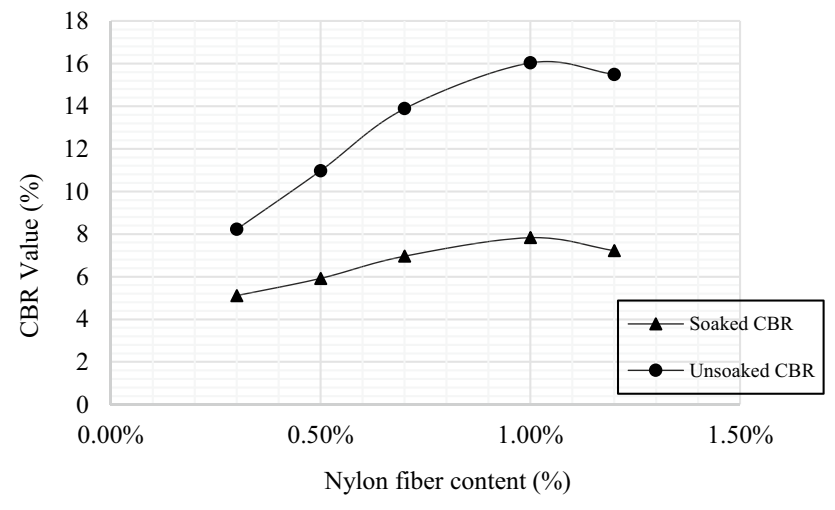

Fig. 11 Variation of CBR value for different content of nylon fiber in $15 \%$ RHA plus soil mixture

- The MDD value decreases gradually but OMC value increases due to addition of different percentage of RHA (5\% to $20 \%$ ) in organic soil. The MDD value decreases from 16.66 to $13.08 \mathrm{kN} / \mathrm{m}^{3}$ for RHA treated soil which is about $21.49 \%$ lower than untreated organic soil. The OMC value increases from 12.23 to $16.88 \%$ for RHA treated soil which is around $38 \%$ higher than plain organic soil.

- Addition of different percent of RHA in organic soil increases UCS value up to $78.33 \mathrm{kPa}$ at $15 \%$ RHA and beyond that UCS value decreases with increase in RHA content. It gives $86.41 \%$ more strength than untreated organic soil. The optimal RHA dosages corresponding to highest UCS value is initiated to be $15 \%$.

- Addition of different percent of RHA in organic soil increases soaked and unsoaked CBR value up to $4.48 \%$ and $6.67 \%$ respectively at $15 \%$ RHA and beyond that unsoaked and soaked CBR value is found to decrease with increase in RHA content. It illustrates that there is an increment in soaked and unsoaked CBR value about $48.35 \%$ and $31.29 \%$ respectively as compared to plain organic soil.

- When different percent of nylon fiber $(0.3-1.2 \%)$ is added in optimum percent of RHA (15\%) plus soil mixture, the MDD value decreases whereas OMC value increases progressively. The MDD value decrease about $24.36 \%$ and $75.92 \%$ as compared to RHA treated soil and untreated organic soil respectively. In contrast, the OMC value increase approximately $24.68 \%$ and $75.55 \%$ as compared to RHA stabilized soil and plain organic soil respectively.

- Inclusion of different dosages of nylon fiber in optimum percentage of RHA (15\%) plus soil mixer increases UCS value up to $148.11 \mathrm{kPa}$ at $1.0 \%$ nylon fiber and after that UCS value is found to decrease with increase in nylon fiber dosages. It clarifies that there is about $66.98 \%$ increase in UCS value as compared to RHA stabilized soil and about $252.48 \%$ increase in UCS value as compared to regular organic soil.

- Inclusion of different content of nylon fiber into optimum percentage (15\%) of RHA treated soil increases unsoaked and soaked CBR value up to $16.03 \%$ and $7.83 \%$ respectively at $1.0 \%$ nylon fiber and thereafter unsoaked and soaked CBR value decreases with increase in nylon fiber content. There is an increment in soaked and unsoaked CBR value about $95.01 \%$ and $53.23 \%$ respectively as compared to RHA treated soil. Again, there is an increment in soaked and unsoaked CBR value about $215.55 \%$ and $159.27 \%$ respectively as compared to plain organic soil.

- The best results or considerable improvements are found for the mix proportion of "soil + 15\% RHA +1.0\% nylon fiber". This particular mix proportion shows significant effect than any other mix proration.

- It is clear that the united effect of RHA and nylon fiber can improve strength properties of poor or weak organic soil. This may occur due to cohesion properties of soil sample, increasing tensile strength of adding randomly distributed nylon fiber and adhesion properties of RHA. The construction site having low bearing capacity can be developed by combined effect of RHA and nylon fiber and bring down the cost of construction.

The disposal of RHA is a huge threat in high rice productive country like Bangladesh. The usage of RHA in soil improvement is particularly attractive because it decreases the environmental effect, disposal expenses and sustains nonrenewable resources such as soils and rocks. The use of waste nylon fiber in ground improvement is also a solution against the disposal of wastes.

Acknowledgements Authors are grateful to the Head of Civil Engineering department, who gave us opportunity for using the labs and instruments. Authors also thankful to the Geotechnical Engineering and Transportation Engineering lab assistants of Khulna University of Engineering and Technology (KUET), who helped us to set up the machine as well as physically and mentally.

\section{Compliance with ethical standards}

Conflicts of interest The authors announce that they have no conflict of interest concerning the publication of this research.

\section{References}

1. Hejazi SM, Sheikhzadeh M, Abtahi SM, Zadhoush A (2012) A simple review of soil reinforcement by using natural and synthetic fibers. Constr Build Mater 30:100-116

2. Chmeisse C (1992) Soil stabilization using some pozzolanic industrial and agricultural product. Doctor of Philosophy 
thesis. Department of Civil and Mining Engineering. University of Wollogong. https://ro.uow.edu.au/cgi/viewconten t.cgi?article $=2268 \&$ context $=$ theses

3. Islam MR, Alamgir M, Bashar MA (2013) Assessment and verification of geotechnical parameters of Reconstituted organic soil at south western region in Bangladesh. J Eng Sci 3(4):67-83

4. Wong LS, Hashim R, Ali FH (2008) Behavior of stabilized peat soil in unconfined compression tests. Am J Eng Appl Sci 1(4):274-279

5. Ling HI, Leshchinsky D, Tatsuoka F (eds) (2003) Proceedings of reinforced soil engineering: advances in research, Columbia University, 544 p, Pub. Marcel Dekker Inc.

6. Islam SU, Hasan S, Alam M, Molla MKA (2015) Building foundation practice on deep layer of soft to medium stiff soil having low bearing capacity in Khulna city, Bangladesh. In: International conference on recent innovation in civil engineering for sustainable development (IICSD), DUET, Paper ID: GE-013, pp 424-429

7. Molla SI, Malik AR (1997) Statistical evaluation of bearing capacity of shallow foundation and pile capacity in Khulna sub-soil. Undergraduate project report, KUET, Khulna

8. Sarkar G, Islam MR, Alamgir M, Rokonuzzaman M (2012) Interpretation of rice husk ash on geotechnical properties of cohesive soil. Glob J Res Eng Civ Struct Eng 12(2):1-7

9. Rabbee T, Islam MR (2012) Strength and compressibility characteristics of reconstituted organic soil at Khulna region of Bangladesh. Int J Eng Technol 2(10):1672-1681

10. Bashar MA, Biswas T (2016) Study on stabilization of organic soil with fly ash. In Proceedings of the 3rd international conference on civil engineering for sustainable development (ICCESD), KUET, Khulna, Bangladesh, pp 970-976

11. Abbasi N (2011) The role of anions in dispersion potential of clayey soil. J Agric Eng Res 12(3):15-30

12. Abbasi N, Nazif MH (2013) Assessment and modification of Sherard chemical method for evaluation of dispersion potential of soils. J Geotech Geol Eng 31(1):337-349. https://doi. org/10.1007/s10706-012-9573-7

13. Afsharian AA, Abbasi N, Khosrojerdi A, Sedghi H (2016) Analytical and laboratory evaluation of the solubility of Gypsiferrous soils. Civ Eng J 2(11):590-599

14. Rahimi H, Abbasi N, Shantia H (2011) Application of geomembrane to control piping of sandy soil under concrete canal lining (case study: Moghan irrigation project, Iran). J Irrig Drain Eng 60:330-337. https://doi.org/10.1002/ird.574

15. Abbasi N, Bahramloo R, Movahedan N (2015) Strategic planning for remediation and optimization of irrigation and drainage networks: a case study for Iran. Agric Agric Sci Procedia 4:211-221. https://doi.org/10.1016/j.aaspro.2015.03.025

16. Rahimi $\mathrm{H}$, Abbasi $\mathrm{N}$ (2008) Failure of concrete canal lining on fine sandy soils (a case study for Saveh Project). J Irrig Drain ICID 57:83-92. https://doi.org/10.1002/ird.350

17. Umesha TS, Dinesh SV, Sivapullaiah PV (2009) Control of dispersivity of soil using lime and cement. Int J Geol 3(1):8-16

18. Prusinski JR, Bhattacharja S (2016) Effectiveness of portland cement and lime in stabilizing clay soils. Transp Res Rec 1652:215-227. https://doi.org/10.3141/1652-28

19. Muntohar AS (2009) Influence of plastic waste fibers on the strength of lime-rice husk ash stabilized clay soil. Civ Eng Dimens 11(1):32-40

20. Okafor FO, Okonkwo UN (2009) Effects of rice husk ash on some geotechnical properties of lateritic soil. Leonardo Electron J Pract Technol 15:67-74

21. Uchariya GS, Arya R (2016) Trivedi MK stabilization of clay by using wood ash and fly ash. IJSRD Int J Sci Res Dev 4(4):667-670
22. Yoobanpot $N$, Jamsawang $P$ (2016) Impact of fineness on strength behavior of bottom ash stabilized soil. Electron J Geotech Eng (EJGE) 21(15):5129-5141

23. Negi P, Sarkar R (2013) Effect of curing on compaction behavior of pond ash mixed with marble dust and lime. Int J Earth Sci Eng 6(1):211-216

24. Ahmed B, Rahman A, Das J (2015) Improvement of subgrade CBR value by using Bagasse ash and Eggshell powder. Int J Adv Struct Geotech Eng 4(2):86-91

25. Junfeng S, Xuewu Z, Daisheng S, Jianguo F, Zhijun L, Zhongmin $L$ (2008) Soil improvement with coal ash and sewage sludge: a field experiment. Environ Geol 53(8):1777-1785. https://doi. org/10.1007/s00254-007-0783-x

26. Moses GK, Saminu A (2012) Cement kiln dust stabilization of compacted black cotton soil. EJGE 17:825-836

27. Chandak NR, Babu A (2015) Effect of lime sludge on strength and compaction of soil. J Civ Eng Res 5(1):18-20. https://doi. org/10.5923/j.jce.20150501.03

28. Mudgal A, Sarkar R, Sahu AK (2014) Effect of lime and stone dust in the geotechnical properties of black cotton soil. Int J GEOMATE 7(2):1033-1039

29. Sabat AK (2012) Stabilization of expansive soil using waste ceramic dust. Electron J Geotech Eng 17:3915-3926

30. Onyelowe KC, Okafor FO, Nwachukwu DG (2012) Geophysical use of quarry dust (as admixture) as applied to soil stabilization and modification-a review. ARPN J Earth Sci 1(1):6-8

31. Muthayya S, Sugimoto JD, Montgomery S, Maberly GF (2014) An overview of global rice production, supply, trade, and Consumption. Ann N Y Acad Sci 1324(1):7-14. https://doi.org/10.1111/ nyas. 12540

32. Alhassan M, Mustapha AM (2007) Effect of rice husk ash on cement stabilized laterite. Leonardo Electron J Pract Technol 11:47-58

33. Farooque KN, Zaman M, Halim E, Islam S, Hossain M, Mollah YA, Mahmood AJ (2009) Characterization and Utilization of Rice Husk Ash (RHA) from Rice Mill of Bangladesh. Bangladesh J Sci Ind Res 44(2):157-162

34. Houston DF (ed) (1972) Rice hulls. In: Rice: chemistry and technology. American Association of Cereal Chemists. St. Paul, MN, pp 301-352

35. Boateng AA, Skeete DA (1990) Incineration of rice hull for uses as a cementitious material. The Guyana Experience. Cem Concr Res 20(5):795-802

36. Basha EA, Hashim R, Mahmud HB, Muntohar AS (2005) Stabilization of residual soil with rice husk ash and cement. Constr Build Mater 19:448-453

37. Nair DG, Fraaij A, Klaassen AK, Kentgens PM (2008) A structural investigation relating to the pozzolanic activity of rice husk ashes. J Cement Concr Res 38(6):861-869

38. Choobbasti AJ, Ghodrat $\mathrm{H}$, Vahdatirad MJ, Firouzian S, Barari A, Torabi M, Bagherian A (2010) Influence of using rice husk ash in soil stabilization method with lime. Front Earth Sci China 4(4):471-480. https://doi.org/10.1007/s11707-010-0138-x

39. Alhassan $M$ (2008) Permeability of lateritic soil treated with lime and rice husk ash. Assumpt Univ J Thail 12(2):115-120

40. Alhassan $M$ (2008) Potentials of rice husk ash for soil stabilization. Assumpt Univ J Thail 11(4):246-250

41. Wang L, Cementitious Stabilization of Soils in the Presence of Sulfate, Ph.D. thesis, Louisiana State University, Baton Rouge, LA, USA, 2002

42. Pannu A (2016) Effect of soil stabilization in construction of roads and strength improvement. Int J All Res Educ Sci Methods (IJARESM) 4(8):99-103

43. Estabragh AR, Bordbar AT, Javadi AA (2011) Mechanical behavior of a clay soil reinforced with nylon fibers. Geotech Geol Eng 29:899-908. https://doi.org/10.1007/s10706-011-9427-8 
44. Sivakumar Babu GL, Vasudevan AK (2008) Strength and stiffness response of coir fiber-reinforced tropical soil. J Mater Civ Eng ASCE 20(9):571-577. https://doi.org/10.1061/ (ASCE)0899-1561(2008)20:9(571)

45. Estabragh AR, Bordbar AT, Javadi AA (2013) A study on the mechanical behavior of a fiber-clay composite with natural fiber. Geotech Geol Eng 31(2):501-510

46. Consoli NC, Montardo JP, Prietto PDM, Pasa GS (2002) Engineering behavior of sand reinforced with plastic waste. J Geotech Geoenviron Eng 128(6):462-472

47. Pradhan PK, Kar RK, Naik A (2012) Effect of random inclusion of polypropylene fibers on strength characteristics of cohesive soil. Geotech Geol Eng 30:15-25. https://doi.org/10.1007/s1070 6-011-9445-6

48. Mishra B (2016) A study on cotton fiber stabilize soil and its effect on CBR value. Int J Sci Res 5(2):828-831

49. Kumar D, Nigam S, Nangia A, Tiwari S (2015) California bearing ratio variations in soil reinforced with natural fibres (a case study bhopal bypass road). Int J Emerg Technol 6(2):95-104

50. Singh HP (2013) Effect of coir fiber on CBR value of Itnagar soil. Int J Curr Eng Technol 3(4):1283-1286

51. Singh HP, Sharma A, Chanda N (2011) Study of strength characteristics of coir reinforced soil. In: International conference on advances in material and techniques for infrastructure development held at NIT Calicut Kerala, India

52. Gray DH, Ohashi $H$ (1983) Mechanics of fiber reinforcing in sand. J Geotech Eng ASCE 112(8):335-353

53. Tang C, Shi B, Gao W, Chen F, Cai Y (2007) Strength and mechanical behavior of short polypropylene fiber reinforced and cement stabilized clayey soil. Geotext Geomembr 25(3):194-202

54. Tang CS, Shi B, Zhao LZ (2010) Interfacial shear strength of fiber reinforced soil. Geotext Geomembr 28(1):54-62

55. Sharan A (2011) Strength characteristics of fibre reinforced compacted pond ash. M. Tech Thesis. Department of Civil Engineering, National Institute of Technology, Rourkela, Odisha, India

56. Sen A, Kashyap R (2012) Soil stabilization using waste fiber materials. B. Tech Thesis. Department of Civil Engineering, National Institute of Technology (NIT), Rourkela, India

57. Kumar S, Tabor E (2003) Strength characteristics of silty clay reinforced with randomly oriented nylon fiber. Electron J Geotech Eng EJGE 8:10

58. Malekzadeh M, Bilsel H (2012) Effect of polypropylene fiber on mechanical behaviour of expansive soils. Electron J Geotech Eng 17:55-63

59. Singh HP (2011) Strength characteristics of fly ash reinforced with geosynthetic. Int J Earth Sci Eng 6(4):969-971

60. Singh HP (2012) Improvement in CBR value of fly ash reinforced with coir fiber. In: 3rd international conference on natural polymer, Mahatma Gandhi University Kottayam, Kerala, India

61. Shingade DN, Parbat DK, Bajad SP (2015) Performance studies on unconfined compressive strength of fly ash mixed expansive soil reinforced with nylon fibers. Int J Mod Trends Eng Res 2(2):32-38

62. Mahesh $\mathrm{CH}$, Rao AS (2016) Effect of nylon fibers \& rice husk on engineering properties of soils. Int J Innov Technol 10:1828-1835

63. Das BM (2015) Principles of foundation engineering. Cengage learning, Boston

64. Naeini SA, Naderinia B, Izadi E (2012) Unconfined compressive strength of clayey soils stabilized with waterborne polymer. KSCE J Civ Eng 16(6):943-949

65. Roy A (2014) Soil stabilization using rice husk ash and cement. Int J Civ Eng Res 5(1):49-54

66. Khan T, Saxena AK, Arora TR (2013) Performance evaluation of locally available soil mixed with fly ash and randomly distributed Nylon fibers. IOSR J Mech Civ Eng (IOSR-JMCE) 9(5):15-19
67. Rajan BH, Subrahmanyam N (1982) Research on rice husk ash for stabilizing black cotton soil. Highw Res Bull 17:61-74

68. Ramadhansyah PJ, Bakar BHA, Johari MAM, Ibrahimm MHW (2011) Strength and permeability properties of concrete containing rice husk ash with different grinding time. Cent Eur J Eng 1(1):103-111

69. Punthutaecha K, Puppala AJ, Vanapalli SK, Inyang H (2006) Volume change behaviors of expansive soils stabilized with recycled ashes and fibers. J Mater Civ Eng 18(2):295-306

70. Sharma RK (2014) Effect of substitution of cement with rice husk ash on compressive strength of concrete using plastic fibres and super plasticizer. KSCE J Civ Eng 18(7):2138-2142. https://doi. org/10.1007/s12205-014-0634-8

71. Sabat AK (2012) Effect of propylene fiber on engineering properties of rice husk ash-lime stabilized expansive soil. Electron J Geotech Eng (EJGE) 17:651-660

72. Sabat AK, Pradhan A (2014) Fiber reinforced- fly ash stabilized expansive soil mixes as subgrade material in flexible pavement. EJGE 9:5757-5770

73. Jain PK, Jain R (2006) Behavior of black cotton soil with stone dust and nylon fiber. In: Proceedings of national conference on natural disaster management, Vizagapatam, pp 149-150

74. Khan MNN, Jamil M, Kaish ABMA, Zain MFM (2014) An overview on manufacturing of rice husk ash as supplementary cementitious material. Aust J Basic Appl Sci 8(19):176-181

75. Vishnu TC, Rasheed R, Shadiya K, Rameesha K, Sreelakshmi TR, Parvathy KM (2016) Soil Stabilization using rice husk ash, lime and jute. SSRG Int J Civ Eng SSRG-IJCE 3(2):20-29

76. ASTM DE854-14 (2014) Standard test methods for specific gravity of soil solids by water pycnometer. American Society for Testing of Materials, Pennsylvania

77. ASTM D4318-00 (2000) Standard test methods for liquid limit, plastic limit, and plasticity index of soils. American Society for Testing of Materials, Pennsylvania

78. ASTM D2976-15 (2015) Standard test method for PH of peat materials

79. ASTM E112-13 (2013) Standard test method for determining average grain size

80. ASTM D698-12 (2012) Standard test methods for laboratory compaction characteristics of soil using standard effort. ASTM International, West Conshohocken. https://doi.org/10.1520/ d0698-12

81. ASTM D2166-06 (2006) Standard test method for unconfined compressive strength of cohesive soil. American Society for Testing of Materials, West Conshohocken

82. ASTM D1883-16, (2016) Standard test method for California Bearing Ratio (CBR) of laboratory-compacted soils. ASTM International, West Conshohocken. https://doi.org/10.1520/d1883 $-16$

83. Ramesh A, Kumar M (2009) An experimental investigation on coir fiber and fly ash in stabilized mechanistic pavements. IGC, Guntur, pp 201-204

84. Gupta D, Kumar A (2016) Strength characterization of cement stabilized and fiber reinforced clay-pond ash mixes. Int J Geosynth Ground Eng 2(32):1-11

85. Muntohar AS (2002) Utilization of uncontrolled burnt rice husk ash in soil improvement. Dimensi Teknik Sipil 2(4):100-105

Publisher's Note Springer Nature remains neutral with regard to jurisdictional claims in published maps and institutional affiliations. 